\title{
Impacts of Covid-19 on travel intention for summer 2020: a trend in proximity tourism mediated by an attitude towards Covid-19
}

\author{
Anne-Marie Lebrun ${ }^{1,2}$ (D) $\cdot$ Roxane Corbel $^{1,2} \cdot$ Patrick Bouchet $^{1,2}$
}

Received: 14 October 2020 / Accepted: 23 June 2021 / Published online: 4 July 2021

(C) The Author(s), under exclusive licence to Springer-Verlag GmbH Germany, part of Springer Nature 2021

\begin{abstract}
This exploratory study examines the impact of the Covid-19 pandemic on the travel intention of French people $(n=655)$ for holidays in summer 2020. Qualitative results show demographic and generation differences in the intention to go on vacation caused by a combination of personal uncertainties due to the pandemic, compulsory state measures and travel bans. Using PLS-SEM, quantitative results indicate that influence of perceived risks and attitude towards Covid-19 led tourists to seek out greater proximity when considering vacation travel. The findings may help tourism managers apply proximity marketing strategies using more local and digital services during global health crises.
\end{abstract}

Keywords Covid-19 $\cdot$ Proximity tourism $\cdot$ Travel intention $\cdot$ Attitude $\cdot$ Generation

\section{Introduction}

Since the advent of the Covid-19 health crisis, many professional and scientific studies have been carried out to measure its health, economic and social impacts at the worldwide, continental, national and local levels (Lew 2020; Cabello et al. 2020; Romagosa 2020). From the beginning of the restrictions (in Europe, these generally began in March), airlines and tourist operators have sought to evaluate the unprecedented financial losses caused by the absence of foreign tourists. Between March

Anne-Marie Lebrun

anne-marie.lebrun@u-bourgogne.fr

Roxane Corbel

corbel.roxane@gmail.com

Patrick Bouchet

patrick.bouchet@u-bourgogne.fr

1 University of Burgundy, Dijon, France

2 UBFC Université de Bourgogne Franche Comté, BP 27877, 21078 Dijon Cedex, France 
and June 2020, Europeans considering a summer vacation were still unsure whether they could leave the area in which they lived, in light of the worldwide spread of the pandemic. Furthermore, given the number of confirmed cases and deaths, they were also likely to question whether or not they should take a trip, not only because of the lack of time and money, but also the risks of travelling to particular destinations in terms of, for example, transportation, accommodation, visits and the number of other tourists and residents present. In this context, tourism companies and operators forecast a significant loss of revenue and dividends worldwide for 2020, especially over the summer vacation period. At the same time, some professionals were predicting the development of a more locally based or domestic form of tourism, whilst some governments, particularly in Europe, were encouraging their population to take vacations in their own countries to support the activity of this sector and reduce the financial impact of the pandemic. A key research question arises from these factors: has the impact of Covid-19 generated more proximity tourism at the regional, interregional or national level? If it has, what variables might explain this trend?

Some studies have already measured the impact of global crises on tourism providers and tourist behaviours, whether in relation to terrorist events (September 11, the Mumbai hotel attack), health crises (such as the H1N1/SARS epidemic), geopolitical conflicts (wars or the Arab Spring) or social unrest (strikes in France or Asia) (Cahyanto et al. 2016; Ritchie and Campiranon 2014; Wen 2005; Wilks et al. 2006). Studies focusing on health crises indicate that perception of the risks linked to the stay and personal attitudes towards the epidemic both have a strong impact on tourists' intention to travel at all, whether to do so alone or with their families and whether to stay in certain types of accommodation (Cahyanto et al. 2016; Ritchie and Campiranon 2014). Considering that physical interpersonal relationships trigger virus transmission and that the risk for severe illness from Covid-19 increases with age, with older adults at highest risk, it is likely that age or generation might moderate tourists' travel intentions in this specific context. Indeed, according to Pennington-Gray et al. (2003), cohort generations, as segmentation variable, have played an important role in determining an individual's tourism preferences, behaviour and demand as different generations have different lifestyles and therefore will be attracted to different activities at different times.

The objective of this exploratory study is therefore to understand the impact of Covid-19 on French tourists' intention to travel during the 2020 summer holiday period. More precisely, we set out to examine whether the pandemic has caused tourists to become more proximity-seeking in their travel intentions, and if so, to identify the explanatory causes or variables associated with this trend.

\section{Literature review}

\subsection{Geographic impact of Covid-19: a trend towards proximity in travel intention}

According to Romagosa (2020), the Covid-19 outbreak has already had a very significant impact on tourism, triggering important changes in mobility, social behaviour, consumption patterns and leisure. This is based on the proposition that the 
increase in social and environmental concerns (Lew 2020) will encourage post-crisis tourists to choose destinations closer to where they live. In a world of increasing insecurity and uncertainty, nearby destinations may be considered less risky by many potential tourists, particularly as their purchasing power may also have been affected by the economic crisis resulting from the pandemic. Moreover, restrictions of some kind are likely to be imposed on international long-distance travel for some time to come, based on the situation in the second quarter of 2020. According to Romagosa (2020) and Cabello et al. (2020), one of the consequences of the Covid19 crisis has been the boosting of proximity tourism, whether within a country (i.e., domestic tourism), in a region, or in some part of the border areas between one's home country and neighbouring states. Trip duration may also have been affected, with vacations restricted to a day, a few days or a week.

Domestic tourism is a neglected topic in the literature, with virtually no empirical data available. Its importance to the economy has generally been underestimated (Canavan 2013; Cortes-Jimenez 2008; Hudson and Ritchie 2002; Stylidis et al. 2017; Yang et al. 2014; Wynen 2013). However, domestic tourism is actually more important than inbound tourism for many European countries. Indeed, it accounts for $65 \%$ of internal tourism expenditure in the EU28 nations, compared with $35 \%$ for inbound tourism (TSA 2019). In almost every European country, domestic tourism makes a significant contribution to the economy, with nearly half such expenditure linked to same day visits. However, it is also well known that official tourism data exclude day visitors, resulting in many destinations being unable to accurately account for their visit numbers (Wynen 2013). This is certainly the case for France, which does not identify same day visitors in its data. According to DGE (2018), tourism consumption in France in 2018 amounted to $€ 107$ billion from French tourists and same day visitors, with $€ 66$ billion from foreign tourists. In 2018, internal tourism consumption accounted for $7.4 \%$ of French GDP (4.5\% for French and $2.9 \%$ for foreign tourists). The departure rate (at least one night spent away from home) for French people reached $69.7 \%$ for metropolitan France and 25.2\% for stays abroad or in overseas territories (DGE 2018). According to Eugenio-Martin and CamposSoria (2014), residents of France and Italy are more likely to travel domestically. Moreover, according to Canavan (2013), domestic tourism is widely acknowledged to induce a redistribution of national income from richer, typically metropolitan areas to poorer, usually rural and more isolated ones (Pearce 1990).

According to Jeuring (2017), unlike the international trips that tourists dream about, domestic tourism often takes place in a context that is relatively close to, or even the same as, one's familiar everyday environment. Some researchers do not even use terms like domestic tourist or domestic tourism, even if their sample consists of this type of traveller (Chen and Tsai 2007; Qu et al. 2011; Wang and Hsu 2010). However, domestic tourists are more likely to be familiar with what the destination has to offer; this means their image of the location may be more complex and multifaceted than that of international tourists, who often have only vague perceptions of a given destination (Lebrun and Corbel 2019). This dichotomy between exotic, different and attractive faraway places and the familiar, mundane local area, a place from which one seeks primarily to escape (Salazar 2012), has been reinforced in recent years. This has increased competition between destinations and has led to 
polarized destination images through associations with the geographical distance between home and elsewhere (Jeuring and Haartsen 2017; Larsen and Guiver 2013). A few months ago, domestic holidays might have been considered old-fashioned, but a revival now seems to be taking shape amidst the Covid-19 crisis.

In Europe, nearly half of domestic tourism expenditure is linked to same day visits, which can also be termed proximity tourism (TSA 2019). Since domestic tourists tend to travel shorter distances (Fennell 2008), proximity tourists may come from neighbouring areas for a weekend or short stay (Canavan 2013; Jeuring 2017), or an overnight or same day trip (at least four hours' duration; Wynen 2013).

Recently, a definition of proximity tourism has been proposed that highlights accessing local destinations, travelling short distances and using lower-carbon modes of transport, as well as capturing 'the mundane exceptionality of the ordinary' (Rantala et al. 2020, p. 1). The concept of proximity tourism (Diaz-Soria 2017; Jeuring and Haartsen 2017) revolves around the notion that in a hypermobile world where everybody has become a tourist and every place can be a destination (Franklin and Crang 2001), touristic experiences of engaging with the 'other', negotiating between familiarity and unfamiliarity (Kastenholz 2010; Szytniewski et al. 2017) and the general purpose of tourism are all connected. Such experiences have become strongly embedded in everyday life and decoupled from the idea of travelling long physical distances, termed Distant Travel Destination (DTD; Jeuring and Haartsen 2016). Accordingly, we propose the first research question:

RQ1: Covid-19 influences summer vacations in 2020 with a greater contribution of Proximity Tourism (PT) in French tourists' travel intention.

\subsection{Generational impact of Covid-19: a moderating role in travel intention}

Introduced by Karl Mannheim (1952), the generational cohort theory was extended by Strauss and Howe (1991) in their work 'History of America's Future (1584 to 2069)'; it was then incorporated into marketing by Noble and Schewe (2003) and into tourism by Pennington-Gray and Spreng (2001) and PenningtonGray et al. (2002, 2003). Strauss and Howe (1991, p. 60) define a generation as 'a cohort group whose length approximates the span of a phase of life and whose boundaries are fixed by peer personalities'. A generational cohort refers to a group of people who were born in the same time period, who go through their lives together, and who have therefore experienced similar external events in their late adolescent and early adult years (Meredith and Schewe 1994; Schewe and Noble 2000; Schewe et al. 2000). Each generation is influenced by broad forces (i.e., parents, peers, media, critical economic and social events, and popular culture), which create common value systems distinguishing them from people who grew up in a different period. Every generational cohort shares a common cultural perspective and norms (Noble and Schewe 2003) and has a collective memory (Schuman and Scott 1989). Pennington-Gray et al. (2003) categorize individuals into age cohorts based on generation, on the assumption that their behaviour would have been influenced by epochal events taking place during 
specific periods in their lives. Currently, four generations constitute the majority of the workforce, employees and tourists in America and Western Europe; Baby Boomers, Generation X, Generation Y and Generation Z (Bakendorff et al. 2010; Noble and Schewe 2003; Noble et al. 2004, 2009; Seemiller et al. 2019).

In the tourism literature, generation has played an important role in determining an individual's preferences, behaviour and demand (Pennington-Gray et al. 2003; Prideaux 2004); travel behaviour (Bojanic 2011; Opperman 1995; You and O'Leary 2000); travel consumption (Gardiner et al. 2013; Glover and Prideaux 2008; Huang and Petrick 2009) and attitudes and intention Gardiner et al. (2013). Some significant findings suggest that generational cohort analysis of preferences is useful in the tourism industry because different generations will be attracted to different activities at different times (Pennington-Gray et al. 2003). Baby Boomers and Generations X, Y and Z, whose key dates vary according to author and country (Glover 2010), represent a large part of the tourist population and are significant segments of opportunity for marketers.

Ollivier and Tanguy (2017) along with Rochford (2016) have defined the key dates of these four generations in France. Rochford (2016) defines Baby Boomers in France as people born before 1960 (i.e., aged over 60 in 2020) and who lived through the Glorious Thirties, employment for all and May 1968. This generation is important because of its size and discretionary income (Huang and Petrick 2009). Strauss and Howe (1991) describe it as being made up of people born in an era of optimism and growth and characterized by a quest for self-realization. Baby Boomers were nonconformist rule breakers during their early years (Lyons et al. 2005), but have become more preoccupied with material possessions and money as they have aged (Roberts and Manolis 2000). They refuse to behave like stereotypical old people, but still look for memorable experiences (Patterson et al. 2017) and keep in touch with the latest travel reports and products (Hudson 2010). Baby Boomers are affluent, healthy and active, better educated, IT literate and increasingly confident about using the Internet as an important source for planning their trips.

Rochford (2016) portrays Generation X in France as those born between 1960 and 1980 (i.e., aged 40-60 in 2020). The childhoods of members of Generation X were defined by both parents working full-time or by only one parent supporting them, due to the increased divorce rate. This is the TV generation and the first to use computers. Strauss and Howe (1991) describe Generation X as comprising people who are sceptical about their economic future and realize they will have to work harder to achieve the same standard of living as their parents. Whereas Baby Boomers live to work, Generation X works to live, and so the search for work/life balance is also a hallmark of this generation (Beutell and Wittig-Berman 2008). This generation, which is the first living cohort to have faced mass unemployment, tends to set out to find balance between their private and professional lives rather than spending all their time at work (Bennett et al. 2012). Members of Generation X grew up in a leisure-focused environment in which travel was recognized as important, and would therefore be more inclined to travel despite a busy work and family schedule. This group is known for including particularly active and free-spending leisure travellers (Laliberté 2005). 
Rochford (2016) describes Generation Y in France as those born between 1981 and 1995 (i.e., aged 25-39 in 2020). Compared to Baby Boomers and Generation X, members of Generation $\mathrm{Y}$ tend to prefer jobs that offer more vacation time (Cennamo and Gardner 2008) and have a greater desire for flexible work that will give them sufficient time to take part in leisure activities to achieve relaxation and happiness (Park and Gursoy 2012). Generation Y members are open-minded, optimistic, goal-oriented and highly motivated to achieve success - as they perceive it. They are accordingly image-driven with a strong need for peer acceptance and connection, a sense of fitting in and social networking, which keeps them permanently connected (Dickey and Sullivan 2007; Himmel 2008). This generation is regarded as highly consumption oriented, with sophisticated tastes and strategies for dealing with brands, advertising, pricing and decision-making, and complex shopping preferences (Marjanen et al. 2019).

Finally, Generation Z is defined in France (Rochford 2016) as people born after 1995 (i.e., aged 24 or under in 2020). This will become the youngest and largest consumer group across all generations over the period 2017 through to 2030 (Euromonitor 2018). In France, Generation $Z$ has grown up in the presence of terrorism, both global and local (e.g., the 2015 Paris attacks), economic uncertainty, recession, the mortgage crisis (Gentina 2019) and now the Covid-19 outbreak. Its members are highly educated, individualistic, pragmatic, creative, innovative, open-minded and socially responsible (Euromonitor 2018). They are committed to helping others and are accordingly more tolerant of LGBTQ (Lesbian, Gay, Bisexual, Transgender, Queer) rights; they are also environmentally conscious and more inclined to collective action, based on an awareness of their role in the world and their responsibility to help improve it (Merriman 2015). The most significant characteristic of this generation is the omnipresent use of technology. This generation was the first to be born into an entirely digital world (Bernstein 2015), making its members digital natives who are even more socially connected than previous generations (Ruangkanjanases and Wongprasopchai 2017). Living in the era of social networks and mobile devices makes Generation $\mathrm{Z}$ more prone to engaging in social interaction and to co-creating experiences in the virtual world (Skinner et al. 2018). They are influenced by new media and virtual friends, and are strongly engaged through social media (Yussof et al. 2018). They broadcast, exchange and remix texts and photos on online platforms or in their own blogs. However, whilst this widespread use of technology has produced people who tend to be efficient, its members can also be impatient individuals who want everything quickly (Berkup 2014). On the basis of these analyses, we propose the second research question:

RQ2: There is a generational difference (Baby Boomers, Generations X, Y or Z) in the impact of Covid-19 on French tourists' travel intention for summer 2020. 


\subsection{Research model of the impact of Covid-19 on Travel Intention: the influences of Perceived Risk, Attitude Towards Covid-19 and Generation}

\subsubsection{Influence of perceived risk}

The concept of Perceived Risk was first introduced into marketing, and more specifically into consumer behaviour, by Bauer (1960) and then expanded within the stream of tourism research by Roehl and Fesenmaier (1992). It has been defined by Mansfeld (2006) as a consumer's perception of the overall negativity of an action that might affect travel behaviour if experienced beyond an acceptable level. According to Roehl and Fesenmaier (1992) tourists make travel decisions based on perceptions rather than reality. Perceived Risk has been studied by many researchers, who have further classified it according to different types of risk, such as performance, financial, physical, psychological, satisfaction, social, political instability, war, disease (including epidemics) and time risks (Floyd et al. 2003; Khan et al. 2019). According to Noh and Vogt (2013), the Perceived Risks of vacationing at a given destination have become especially influential on tourists' decision-making in recent years, given the international awareness of tragic or high-risk events around the globe.

Indeed, with the increase in the frequency of natural disasters and global epidemics, researchers have begun to integrate risk studies measured across different dimensions. Fuchs and Reichel (2006) look at the risk perception of international tourists going to a risky destination, Dolnicar (2005) examines the risk perception of natural disasters and landslides and Moreira (2007) focuses on stealth and catastrophic risks. It has been consistently shown that risk perception has a significant effect on travel intention (Floyd et al. 2003; Sönmez and Graefe 1998a, 1998b), particularly after incidents that are perceived as dangerous have taken place (Floyd et al. 2003; McKercher and Chon 2004; Rittichainuwat 2006; Rittichainuwat and Chakraborty 2009).

This is reinforced when risks such as an epidemic, natural or manmade disasters and terrorism draw the focus of travellers to their safety and security (Rittichainuwat and Chakraborty 2009; Fuchs and Reichel 2006). Perceived Risk could therefore affect travel behaviour (Reichel et al. 2007) and the intention to travel (Floyd et al. 2003). This is expressly the case for disease, which is strongly related to changes in travel plans (Kozak et al. 2007). A few years ago, international travel in the Asia-Pacific region was harmed by severe and tragic events such as the SARS outbreak. McKercher and Chon (2004) show that the perceived risk of SARS had a more devastating effect on tourists' behaviour than the disease itself, and that this effect was observed not only in countries that had SARS cases but also in bordering nations with no reported infections. Cahyanto et al. (2016) point out that Perceived Risk is the strongest predictor explaining propensity to avoid travel. Actually, tourists base their decisions on these (biased) risk perceptions (Roehl and Fesenmaier 1992), which might not represent the actual situation at destination (Fuchs and Reichel 2006). Floyd et al. (2003) developed a four-dimension scale describing risk perceptions. The first dimension is related to travel risk. This Travel Perceived Risk is important in tourism because travel is one of the activities most vulnerable 
to global risk factors (Ritchie 2004). The second dimension, Perceived Safety Risk, is linked to safety concerns, which strongly influence tourists' decision-making processes (Seabra et al. 2013). The third dimension, Distance Perception Comparative Risk, compared international versus domestic travel. This geographic impact will encourage post-crisis tourists to choose destinations closer to where they live (Lew 2020). The last dimension, Perceived Destination Risk, is related to the destination. Seabra et al. (2013) consider that travellers select destinations that have the lowest possible risks and consequently, destinations perceived as being safer may be preferred, and those perceived as risky or unsafe may be rejected (Sönmez 1998). According to Floyd et al. (2003), these four factors could be used to measure Perceived Risk: Travel Perceived Risk (TPR), Perceived Safety Risk (PSR), Distance Perception Comparative Risk (DPCR) and Perceived Destination Risk (PDR).

Therefore, in line with the literature and based on Floyd et al.'s research (2003), we can formulate the following hypotheses:

\section{H1: Perceived Risk will be positively related to Proximity Tourism (PT).}

\subsubsection{Influence of attitude towards Covid-19 and its potential mediating role}

Research on Attitude has received considerable attention in social psychology, marketing and tourism. Attitude towards a destination describes the psychological tendencies that tourists express through their positive or negative evaluations of a destination experience (Lee 2009). It refers to a learned predisposition of tourists to respond in a consistently favourable or unfavourable manner to a given object (Ajzen and Fishbein 2000). Attitude towards an object (e.g., the Covid-19 pandemic) is therefore a function of the belief about the object and its implicit evaluative responses. Tourist attitude is an effective predictor of tourists' choice behaviour (Mohsin 2005; Lee 2009) and tourist participation and satisfaction (Ragheb and Tate 1993). Research exploring individual, latent destination attractiveness factors as antecedents of tourists' cognitive evaluations within a destination context remains rather limited. Um and Crompton (1990), for instance, demonstrated that attitude was found to be influential in determining a potential travel destination choice. Surprisingly little effort has been made to investigate the impact of a perceived risk of sanitary crisis on attitude towards this crisis and on travel intention.

Recently, Nazneen et al. (2020) have demonstrated that the Covid-19 outbreak has affected tourists' attitude towards travel intention in terms of distance (proximity tourism/distant tourism destination). Tourists' perception of risk has a significant negative effect on travel decision-making by creating anxiety around the globe (Floyd et al. 2003). In particular, plans to travel to large and crowded cities may be affected by this, because people consider that this type of travel is becoming unsafe. Attitude towards virus outbreak received some interest from researchers. Wen et al. (2005) developed a scale about the impact of SARS on tourist behaviours. One of the dimensions of this scale (Travelling Attitude) defines the attitude towards travel, which includes tourism inclination and mode of tours. Jittrapirom and Tanaksaranond (2020), adapted from the work of Sadique et al. (2007), developed a measure of precautionary attitude towards travel, including Sanitary Attitude and Material 
Risk. According to Wen et al. (2005) and Jittrapirom and Tanaksaranond (2020), Attitude Towards Covid-19 could be described by Travelling Attitude (TA) and precautionary measures such as Material Risk (MR) and Sanitary Attitude (SA). This reflects the fact that tourists are sensitive to world crises events and that their attitude towards Covid-19 will have affected their intention to travel (Nazneen et al. 2020). As identified by Romagosa (2020) and Cabello et al. (2020), one of the consequences of the Covid-19 crisis is likely to be the boosting of proximity tourism in terms of travel intention. Therefore, we hypothesise the following:

H2: Perceived Risk will be positively related to Attitude Towards Covid-19;

H3: Attitude Towards Covid-19 will be positively related to Proximity Tourism.

Although some research has examined specific antecedents and consequences of pandemics, the majority of studies have assumed a direct relationship between the perception of sanitary risks and travel intention (e.g., George 2010; Reichel et al. 2007). For example, previous research has shown that perceived risk determines attitude, which in turn influences behavioural intention (Ajzen 1985; Quintal et al. 2010) and travel intention (Bae and Chang 2020). This study supposes that attitude towards Covid-19 as primarily depending on mental representations that include destination self cognitions, thoughts, and memories of tourists' experience and destination attractiveness (Reitsamer et al. 2016) or visit intention (Doosti et al. 2016). Perceiving, storing and retrieving mental images of a perceived risk associated to Covid-19 are thus regarded as an important precondition for travel intention on proximity. Drawing on the preceding arguments, we propose:

H4: Attitude Towards Covid-19 will mediate the relationship between Perceived Risk and Proximity Tourism.

\subsubsection{Moderating influence of generation}

Schroeder et al. (2013) show that tourists from different age groups perceive destination risks differently. Wen (2005) indicates that the impact of SARS on older people was much more serious than on younger or middle-aged people. These two studies focus on age rather than generation, but they suggest that there may be differences due to cohorts or circumstances; this is precisely what generational analysis seeks to explore. Nonetheless, few studies have focused on generation as a specific variable, especially in terms of Covid-19. Clements (2020) shows that Baby Boomers have the highest awareness of Covid-related risks. Wise et al. (2020) find that the impact of perceived Covid-related risk is related to protective behaviours. We show that the more concerned people felt, the higher their perception of risk, and the more they engaged in protective behaviours. Unfortunately, the median age of participants in this study was around 30, so this does not fully cover older generations with a higher Covid-19 risk. Breakwell (2014) confirms that anxiety influences risk perception; such anxiety might rise with the media focus on the elderly (including Baby 
Boomers) in the coverage of the pandemic. Indeed, there has been a strong focus on the lethality of the disease amongst older people, who are seen as more at risk than younger generations (Remuzzi and Remuzzi 2020).

It may therefore be expected that this pattern may increase concern for oneself and death-related anxiety amongst Baby Boomers, leading to an increase in selfprotective behaviours. One might therefore expect to see an increase in such risk attitudes across chronologically defined generations, due to a shift in the concern for the self that justifies such biases in risk perception. In other words, the older people are, the more worried they are likely to be about the risk posed by Covid-19, and the more likely it is that this risk perception will affect their travel intentions and lead to an increase in PT. Nonetheless, because of the media focus on the elderly, it is proposed that the attitudes and travel intention of Baby Boomers will be significantly different from the other generations. Therefore, we hypothesize the following:

H5: Generational membership will moderate the relationship:

H5.1: between Perceived Risk and Attitude Towards Covid-19;

H5.2: between Perceived Risk and Proximity Tourism;

H5.3: between Attitude Towards Covid-19 and Proximity Tourism;

H5.4: on the mediation effect of Attitude Towards Covid-19 between Perceived Risk and Proximity Tourism.

Based on this literature review, the objective of this research was accordingly to understand the relationships between Perceived Risk, Attitude Towards Covid-19 and Proximity Tourism amongst French tourists in summer 2020, as moderated by membership of a Generation. The research timing (the survey was open from June 15 to July 15) made it possible to examine any change in the impact of Perceived Risk as mediated by Attitude Towards Covid-19 on Proximity Tourism at the point when the borders of France and certain European countries reopened.

\section{Methodology}

\subsection{Research setting: the context of Covid-19 in France}

Between March 3 and July 10, 2020, the French government ${ }^{1}$ took containment measures to prevent the spread of Covid-19 and limit the number of cases and deaths on national territory (Online Appendix 1). During this short and unprecedented period, many French people found themselves in a paradoxical situation where they wanted to go on vacation (especially those who were living in apartments and with their families) but the health crisis limited travel between countries and contact between people. This was especially the case since they had been accustomed for many weeks to limiting their trips for leisure or short stays to less than

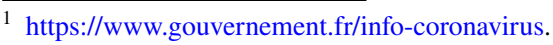


Table 1 Profile of survey respondents-will travel $(n=355)$

\begin{tabular}{|c|c|c|c|c|c|}
\hline Variables & Frequency & Percentage & Variables & Frequency & Percentage \\
\hline \multicolumn{3}{|l|}{ Intention status } & \multicolumn{3}{|l|}{ Employment status } \\
\hline \multirow[t]{2}{*}{ Will travel } & \multirow[t]{2}{*}{355} & \multirow[t]{2}{*}{100} & Full-time & 256 & 72 \\
\hline & & & $\begin{array}{l}\text { Unemployed or } \\
\text { retired }\end{array}$ & 99 & 28 \\
\hline \multicolumn{6}{|l|}{ Gender } \\
\hline Male & 106 & 30 & Location & & \\
\hline \multirow[t]{2}{*}{ Female } & \multirow[t]{2}{*}{249} & \multirow[t]{2}{*}{70} & Urban & 245 & 69 \\
\hline & & & Rural & 110 & 31 \\
\hline \multicolumn{6}{|l|}{ Marital status } \\
\hline Married & 243 & 68 & Generation & & \\
\hline \multirow[t]{2}{*}{ Single/divorced/separated } & \multirow[t]{2}{*}{112} & \multirow[t]{2}{*}{32} & Generation Z & 80 & 22 \\
\hline & & & Generation $\mathrm{Y}$ & 145 & 41 \\
\hline Education background & & & Generation X & 109 & 31 \\
\hline Under-graduate & 229 & 65 & Baby boomers & 21 & 6 \\
\hline Post-graduate & 126 & 35 & & & \\
\hline
\end{tabular}

$100 \mathrm{~km}$ and/or within their country. At the same time, they had little or no purchasing power to consider a long stay in France or abroad in a manner that would ensure optimal health security. In this particular and highly uncertain context, in this study we asked a series of questions to French people about their intention to go on a trip during the summer vacation period in 2020.

\subsection{Data collection and sample design}

Due to the need for social distancing in the actual pandemic crisis scenario, all the necessary information was collected online. The target population of this study was domestic tourists from different French regions. An online survey using LimeSurvey was administered to over 1057 randomly selected adults in these regions during the second half of June and first half of July 2020. This period was chosen because France and some European countries had reopened their borders on June 15. Respondents took an average of $10 \mathrm{~min}$ to complete the survey. A total of 655 usable responses were obtained. The profile of the respondents is summarized in Tables 1 and 2.

\subsection{Questionnaire design}

The survey questionnaire was composed of four sections: (a) geographical travel intention, (b) perceived risk, (c) attitude towards Covid-19 and (d) demographic information (Online Appendix 2). In the four sections, responses were collected using seven-point Likert-type scales. In the first section, the construct of Geographical Travel Intention was estimated using five items adapted from previous 
Table 2 Profile of survey respondents-will not travel and does not know $(n=300)$

\begin{tabular}{|c|c|c|c|c|c|}
\hline Variables & Frequency & Percentage & Variables & Frequency & Percentage \\
\hline Intention status & & & Employment status & & \\
\hline Does not know & 104 & 35 & Full-time & 236 & 66 \\
\hline Will not travel & 196 & 65 & $\begin{array}{l}\text { Unemployed or } \\
\text { retired }\end{array}$ & 119 & 34 \\
\hline Gender & & & Location & & \\
\hline Male & 79 & 26 & Urban & 183 & 61 \\
\hline Female & 221 & 74 & Rural & 117 & 39 \\
\hline Marital status & & & Generation & & \\
\hline Married & 175 & 60 & Generation Z & 102 & 34 \\
\hline \multirow[t]{2}{*}{ Single/divorced/separated } & 101 & 40 & Generation Y & 121 & 40 \\
\hline & & & Generation $\mathrm{X}$ & 57 & 19 \\
\hline Education background & & & Baby boomers & 20 & 7 \\
\hline Under-graduate & 218 & 73 & & & \\
\hline Post-graduate & 82 & 27 & & & \\
\hline
\end{tabular}

research (Floyd et al. 2003; Cahyanto et al. 2016). The measure focused on geographical aspects of intention in a general travel intention rather than an intention to travel in a specific destination. The second section of the survey captured Perceived Risk. Previous studies have conceptualized Perceived Risk as multidimensional, in order to investigate its relationship with visit intention (Khan et al. 2019).

The construct of Perceived Risk in this survey was evaluated using eight items based on previous research (Floyd et al. 2003; Cahyanto et al. 2016). The third section of the survey measured Attitude Towards Covid-19 in terms of travel. The constructs used in this scale are based on previous research (Wen et al. 2005; Jittrapirom and Tanaksaranond 2020). The survey instruments used in sections two and three were developed by considering valid and reliable scales used in previous research. The mobilized constructs and related items are set out in Online Appendix 2. The fourth section collected demographic information including gender, generation, location, marital status, employment status and educational background.

\subsection{Data analysis}

\subsubsection{Step 1}

Firstly, a descriptive analysis of the intention to go on holiday in the next three months was carried out, using SPSS 21.0. The 655 respondents were almost evenly divided between those who did $(54 \%, n=355)$ and did not $(46 \%, n=$ $300)$ intend to do so. 


\subsubsection{Step 2}

Secondly, two analyses focused on the geographical intention of travel for respondents who did intend to go on vacation $(n=355)$ and may explain the trend of proximity tourism. A one-way ANOVA was used to compare the geographical intention of the respondents: intra-regional, close to region, France, Europe and continental. Then, in an analytical step, Exploratory Factor Analysis (EFA) was carried out on the items of the geographical intention to travel to measure and verify their inner structure with the sample.

\subsubsection{Step 3}

Lastly, a partial least squares structural equation model (PLS-SEM) was constructed using SmartPLS3.2.8 to validate the measurement model and test the hypotheses for respondents who did intend to go on vacation $(n=355)$. PLS-SEM was chosen because of the exploratory nature of the work, especially with the Geographical Travel Intention. Moreover, some variables didn't fit the normal distribution either which leads also to PLS-SEM. The process was done using a repeated measure approach. The first-order model was run in a reflective way according to the initial scales previous validation. We followed Hair et al. (2019a, b) recommendations as for the first reflective order and as for the 2nd formative order, and a two-step approach was chosen. We then used GPower software to estimate the sample minimal size to make between-groups comparisons. Multi Group Analysis (MGA) was done following Matthews' (2017) statements using the permutation test to assess invariance and eventual differences between paths amongst generations.

\section{Results}

\subsection{Intention to go on vacation and demographic factors $(n=655)$}

Respondents who did not intend to go on vacation $(46 \%, n=300)$ can be further subdivided into those who had made a definite decision not to travel $(65 \%, n=196)$ and those who had not yet made a final choice $(35 \%, n=104)$ (Table 2$)$. The main reasons cited by those not intending to go on holiday were mainly the Covid-19 outbreak $(46 \%)$, job-related issues $(24 \%)$ or financial problems $(11 \%)$. The main reasons for not having yet made a final decision were the outbreak $(43 \%)$, job-related financial problems $(23 \%)$, cancellations $(15 \%)$ or other job-related issues $(11 \%)$.

Table 3 compares the subgroups reporting intention to travel $(54 \%, n=355)$ and no intention $(46 \%, n=300)$ in terms of the other variables. The results indicate no significant difference in terms of gender or employment status. However, some important and significant differences can be seen in terms of marital status, educational background and location. Married respondents (57\%) were more likely to intend going on vacation than single people (48\%). Respondents with postgraduate-level education $(61 \%)$ were more likely to travel than those with undergraduate qualifications (51\%) and urban dwellers (57\%) were more inclined to go on 


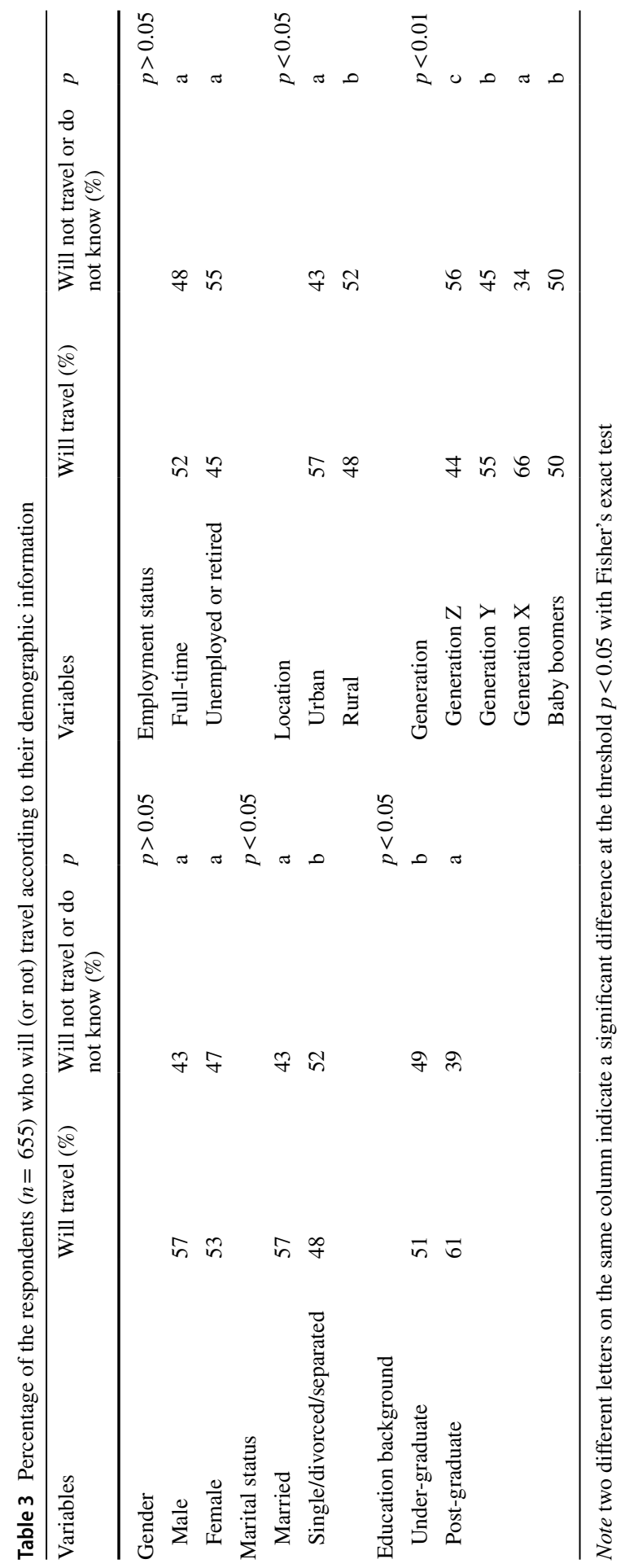


Table 4 Geographical travel intention descriptive statistics

\begin{tabular}{llll}
\hline & Mean & Median & SD \\
\hline PT 1-intra-regional & 3.46 & 3.00 & 2.47 \\
PT 2 - close to region & 3.66 & 4.00 & 2.45 \\
DTD 1-France & 6.09 & 7.00 & 1.82 \\
DTD 2-Europe & 2.89 & 1.00 & 2.46 \\
DTD 3-continental & 1.56 & 1.00 & 1.54 \\
\hline
\end{tabular}

$S D$ standard deviation

vacation than those living in rural areas (48\%). There were also significant differences between generations. Members of Generation X $(66 \%)$ were the most keen to go on vacation, followed by Generation Y (55\%) and Baby Boomers (50\%), with Generation Z (44\%) the least willing. Most people who would not be going on vacation, or who had not yet made a decision, planned to stay at home and make same day visits around their neighbourhood. They answered No to the travel intention question because they did not plan to stay overnight, and so they were not included in the dataset analysed to construct the main model. However, it can be seen that these results support RQ2.

\subsection{Geographical travel intention: domestic and proximity tourism $(n=355)$}

Table 4 compares the plans, in terms of mean geographical distance, of those reporting they intended to travel $(n=355)$. A one-way ANOVA showed a significant difference between the variables $(F=161.1342 ; \mathrm{df}=351 ; p<0.001)$. The Wilcoxon test showed significant differences between all the localization means (all $p$-values $<0.001$; see Online Appendix 3) except for the comparison between intra-regional and close to region $(p=0.134)$. Three patterns emerged, that can be described as regional, national and continental. Regional intention denotes a response close to the middle of the scale, with a high response indicating national travel intention and a very low score denoting the continental response pattern. These results confirmed the hypotheses set out in terms of RQ1.

Regarding the geographical travel intention scale, an EFA was then carried out to validate the distance patterns concerning travel intention identified through the ANOVA. This was done before the PLS-SEM to understand how the items loaded on factors (see Online Appendix 4 for more details). Parallel analysis and principal axis factoring were chosen because of the exploratory nature of the scale but also because of the misidentification of the number of factors found with other methods (Gaskin and Happell 2014). The inner correlation of the constructs showed a reflective structure as the correlation between factors was under 0.32 (Tabachnick and Fidell 2007, p. 646).

A significant result for Bartlett's test of sphericity appeared $\left(\chi^{2}=237, \mathrm{df}=10\right.$, $p<0.001)$. The Keyer-Meyer-Olkin $(\mathrm{KMO}=56.7)$ sample adequacy measure (Kaiser 1974) could be seen as weak, but the cutoff of 0.50 was seen as correct (Hair et al. 2019a, b). Proximity Tourism (PT) explains $19.2 \%$ of the variance and 
Distant Travel Destination (DTD) 22.3\%. It is interesting to note that the middledistance item 'France' loaded on the DTD dimension, but with a negative coefficient (-0.83). This may be explained by the item being indeterminate, respondent error (Schmitt and Suits 1985), or the formulation of the item. The descriptive statistics clearly showed this omission in terms of the opposition of the means between the item 'France' and the Continental/Europe items, which could be seen as a misformulation of the item leading to different understandings amongst participants.

\subsection{Partial least squares structural equation model (PLS-SEM)}

\subsubsection{Measurement model assessment}

The assessment of the measurement model comprised an examination of reliability, convergent validity and discriminant validity. Reliability was checked using Cronbach's alpha, the value of which should exceed the threshold of 0.6 for exploratory research and Composite Reliability (CR), which should exceed 0.7 (De Vellis 2016; Hair et al. 2014; Matsunaga 2010). Discriminant validity was tested using the HeteroTrait-MonoTrait ratio of correlations (HTMT) inference criterion (Online Appendix 5) instead of the Fornell-Larcker criterion; Fornell and Lacker (1981); Henseler et al. (2015) have demonstrated, by means of a Monte Carlo simulation study, that this approach performs better. According to Henseler et al. (2015), the HTMT values must be above 0.85 as the constructs are different. Finally, as a check on convergent validity, the average variance extracted (AVE) must have a value of up to 0.50 . The variables in this study satisfy this test of convergent validity.

Online Appendix 2 shows the original questionnaire whereas Online Appendix 6 summarizes the results of the model assessment, with items falling below the abovementioned statistical thresholds excluded. The material risk dimension of Attitude Towards Covid-19 did not pass the tests; neither did the DTD dimension of Geographical Travel Intention, nor did some items of the kept Low Order Constructs (LOCs) and the PDR (Perceived Distance Risk dimension) (Fig. 1).

\subsubsection{1st order assessment The High Order Construct (HOC) 'Perceived Risk'} index (Floyd et al. 2003) contains four Independent Variables (IVs) which can be seen as LOCs: TPR (Travel Perceived Risk), PSR (Perceived Safety Risk), DPCR (Distance Perceived Comparative Risk) and PDR (Perceived Distance Risk).

The HOC 'Attitude Towards Covid-19' includes three LOCs, namely Travel Attitude (TA), Sanitary Attitude (SA) and Material Risk (MR). As found by the previous EFA, the HOC 'Geographical travel intention' is formed by two LOCs Proximity Tourism (PT) and Distant Travel Destination (DTD). The first step was to assess the 1st order as reflective. Those that did not fit the criteria were not selected, like DTD, MR and PDR. The conceptual model is the following (Fig. 2).

In the final reflective measurement model assessment, all items related to its LOC had loadings above 0.708 and significance levels of $p<0.001$. MR was a factor for which the Cronbach's alpha is below 0.60 and PDR had an alpha of 0.619 , so these LOCs were removed, as items that did not fit the 0.708 threshold of loading. 


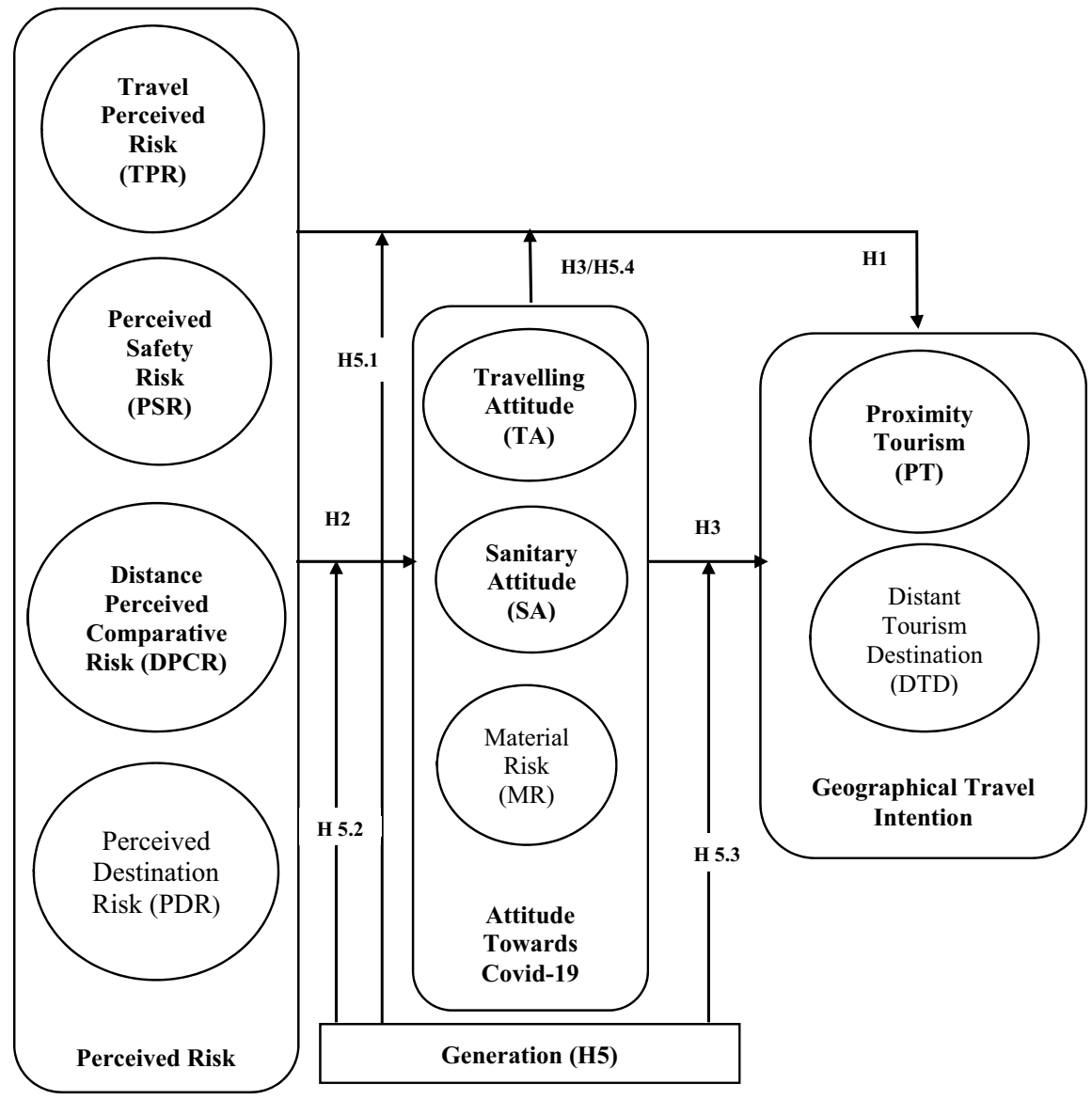

Fig. 1 Research model of the impacts of Covid-19 on geographical travel intention: influences of perceived risk, attitude towards Covid-19 and Generation

All items loaded significantly to their belonging LOC with $p<0.001$. The variance inflation factors (VIF) were less than 3 (Online Appendix 7), which confirmed there are no collinearity issues in the model. The cutoff of 0.50 was respected for Average Variance Extracted (AVE) and meant that LOCs were explained by the variance of their respective indicators. The composite reliability values scored between 0.864 and 0.935 , assessing the construct validity. HTMT criterion scored close or higher than 1 for LOCs on HOCs, which was normal in the repeated approach due to the presence of the same indicators but was below 0.90 for all the in-between LOC comparisons (Online Appendix 5). 


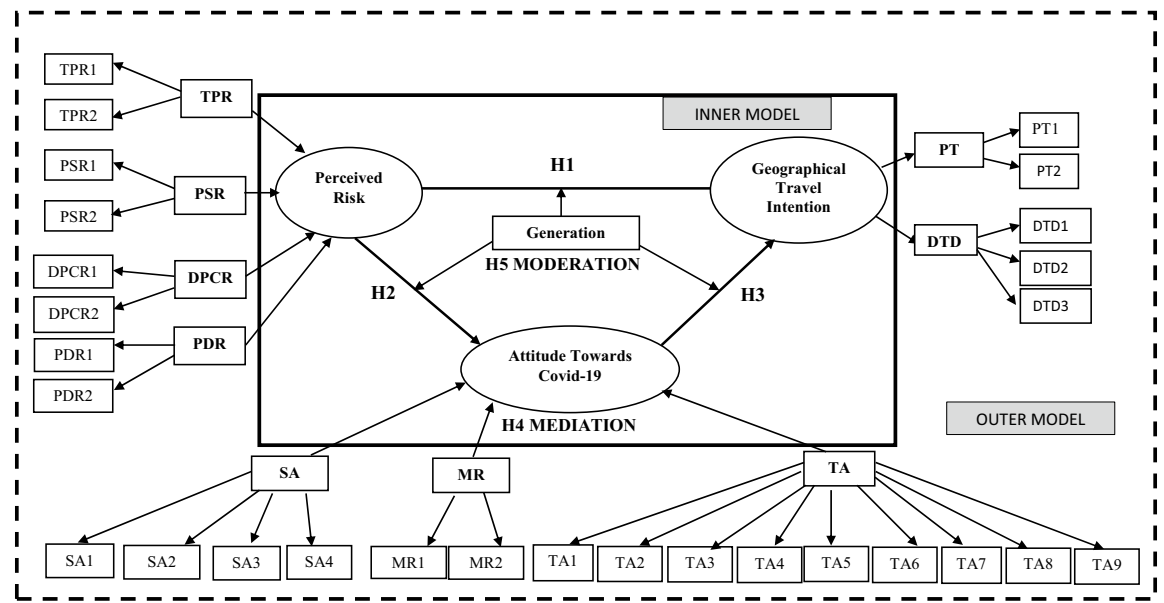

Fig. 2 Inner and outer model 1st order and hypotheses

The interval confidence in the 5000 bootstrap procedure showed no score including 1 or above for the LOCs comparisons ${ }^{2}$ (Franke and Sarstedt 2019). Thus, there was no issue of discriminant validity. We then used latent variable scores of the LOCs and computed them in the data to use them as manifest variables of their belonging HOCs. The further need was the 2 nd order outer model assessment. Once this assessment was done, the inner path model could be run under Ali et al.'s recommendations (2018).

4.3.1.2 2nd order assessment The outer VIF assesses the lack of collinearity and always remained below 3 ; the outer weight and $t$-values were used to assess the formative constructs. The assessment of the high order outer model fit the criterion and is presented in Tables 5 and 6.

\subsubsection{Structural model assessment ( 2 nd order)}

4.3.2.1 Model fit The model fit was correct according to $\mathrm{Hu}$ and Bentler (1998, 1999) because it was below 0.08, and the whole model fit can be seen in Online Appendix 8. Garson (2016, p. 68) explains that SRMR denotes the comparison between the observed and the model-implied correlation matrices; so the lower the SRMR, the better the fit. In our model, SRMR was 0.051 and the $\chi^{2}$ was 35.137 . The $R^{2}$ values were moderate for Attitude Towards Covid-19 $\left(R^{2}=0.465\right)$ and weak for PT $\left(R^{2}=0.038\right)$.

4.3.2.2 Paths results We hypothesized that Perceived Risk would positively influence Proximity Tourism (H1) but surprisingly it was not the case. Indeed, a non-sig-

2 Available upon request. 


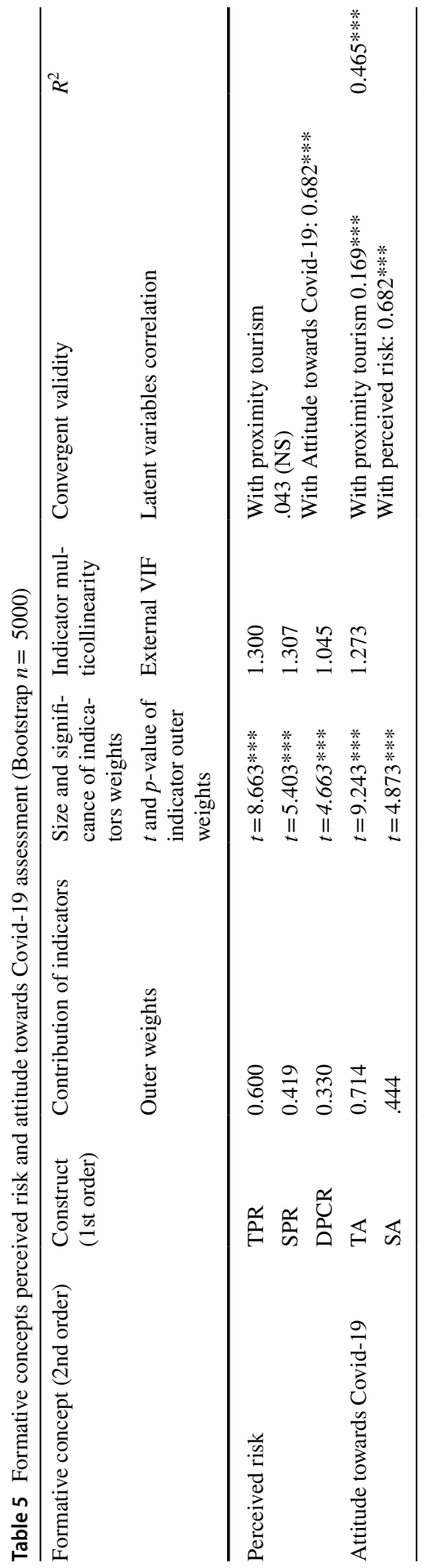




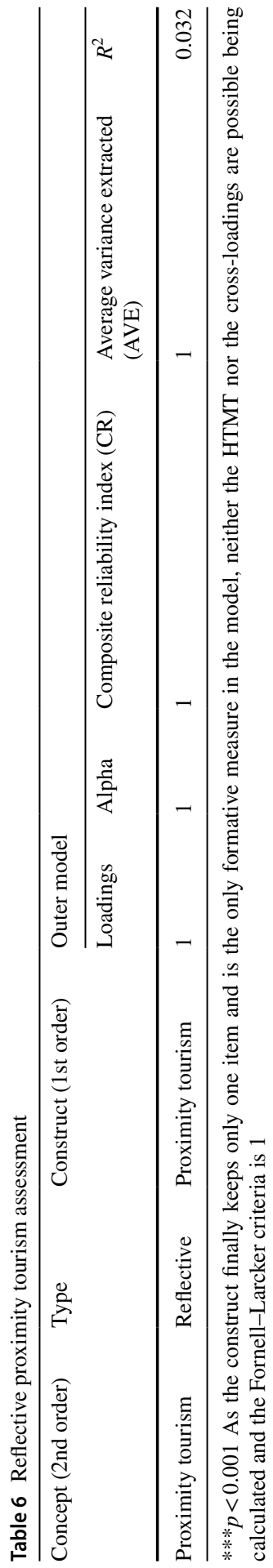


Table 7 Global hypothesis and their respective findings

\begin{tabular}{llrrrr}
\hline Hypothesis & Variables & \multicolumn{1}{l}{ Path } & SD & $t$-value & $p$-value \\
\hline H1 & Perceived risk $\rightarrow$ PT & -0.135 & 0.075 & 1.790 & 0.069 \\
H2 & Perceived risk $\rightarrow$ attitude towards Covid-19 & 0.682 & 0.031 & 22.346 & 0.000 \\
H3 & Attitude towards Covid-19 $\rightarrow$ PT & 0.261 & 0.087 & 3.000 & 0.030 \\
H3 & Perceived risk $\rightarrow$ attitude towards Covid-19 $\rightarrow$ PT & 0.178 & 0.061 & 2.931 & 0.003 \\
\hline
\end{tabular}

$S D$ standard deviation

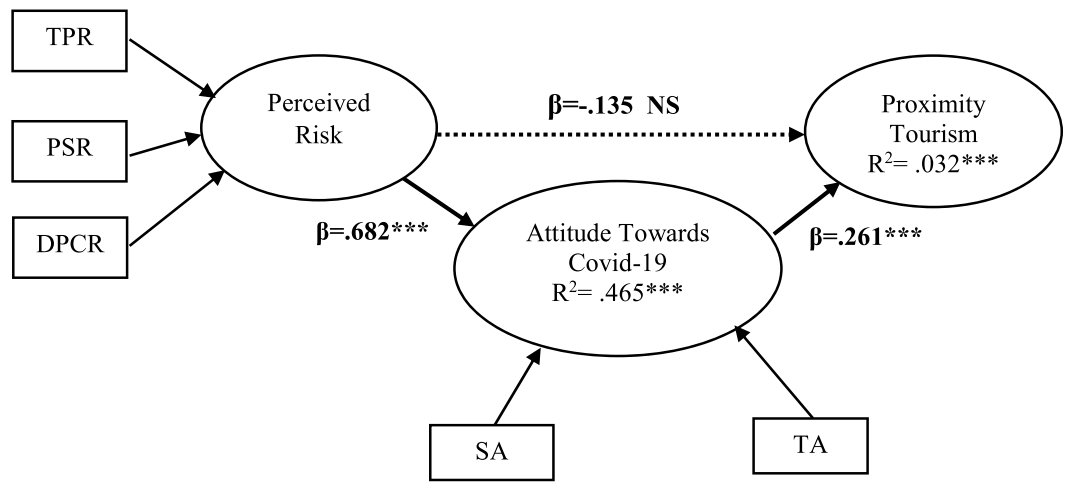

${ }^{*} \mathrm{p}<.05 ;{ }^{* *} \mathrm{p}<.01 ; * * * \mathrm{p}<.001$

Fig. 3 Final structural model (second-order construct)

nificant effect appeared $(\beta=0.077, p>0.05)$. As expected, Perceived Risk positively influenced Attitude Towards Covid-19 (H2; $\beta=0.682, p<0.001$ ), which meant that a high Perceived Risk would enhance high protective Attitude Towards Covid-19. Then, an effect of Attitude Towards Covid-19 was seen as expected by $\mathrm{H} 3$ ( $\beta=0.261$, $p<0.01$ ) for which protective Attitude Towards Covid-19 triggered Proximity Tourism. At least, there was a mediation effect of Attitude Towards Covid-19 on the link between Perceived Risk and Proximity Tourism. The indirect effect was statistically significant (H3; $\beta=0.178, p<0.01 ; C f$. Table 7 and Fig. 3 ), and the direct effect of Perceived Risk on Proximity Tourism was not significant $(\beta=-0.135 ; p>0.05)$, confirming a full mediation effect of Attitude Towards Covid-19 between Attitude Towards Covid-19 and Proximity Tourism.

\subsubsection{Moderating effect of generation}

We used GPower software (Faul et al. 2009) to estimate the required minimum sample size (Lee and Hallak 2018; Melián-González et al. 2021; Rasoolimanesh et al. 2021; Ringle et al. 2015). Selected thresholds (Cohen 1992; Hair et al. 2014) for linear multiple regression (selected fixed model, $\mathrm{R}^{2}$ and deviation from zero) were the following: Effect size $\left(\mathrm{f}^{2}\right)$ at 0.20 , type I error $(\alpha)$ at $p<0.05$ and type II error at $1-\beta=0.80$ for 2 predictors (Perceived Risk and Attitude Towards Covid-19). The 
indicated minimum sample size was $n=52$. Consequently, Baby Boomers $(n=21)$ was not a sample for which MGA seemed possible and was removed from further analysis. The three following generation groups were Generation X $(n=109)$, Generation Y $(n=145)$ and Generation $\mathrm{Z}(n=80)$.

A permutation test $(n=5000) 2$ by 2 was done firstly to verify the invariance in the outer model, as the between-groups hypothesis was two-tailed (Matthews 2017). Permutation tests can be seen in Online Appendix 10. Measurement Invariance of Composite Models (MICOM) procedure assessed the differences between the compared groups. Permutation tests did not show any difference between groups in the configural invariance nor in indicators, criteria and data treatment amongst the groups (step 1), nor in the compositional invariance (step 2) as original correlation is greater than or equal to the $5 \%$ quantile. However, partial invariance appeared in step 3 of the MICOM, which meant that composite mean values and variances were not equal, but allowed group comparison as step 1 and 2 were correct (Henseler et al. 2016). H5 was rejected: there was no difference between generations amongst the effect of Perceived Risk on Proximity Tourism, nor on Attitude towards Covid-19 (Cf. Table 8 and Online Appendices 9 and 10 for details). Attitude towards Covid19 was not different in its impact on Proximity Tourism across generations, as there was no different mediation of Attitude towards Covid-19 on the link between Perceived Risk on Proximity Tourism according to generation.

\section{Discussion and conclusion}

In this section, we highlight the main theoretical contributions of this research paper and discuss the managerial implications of the results. We also consider the limitations of the study and make suggestions for future research.

\subsection{Theoretical contributions}

In this exploratory study, we set out to understand the impact of Covid-19 on the geographical travel intention of French people in summer 2020. The main reasons cited by those not intending to go on holiday were mainly the Covid-19 outbreak (46\%), job-related issues $(24 \%)$ or financial problems $(11 \%)$. The main reasons for not having yet made a final decision were the outbreak (43\%), job-related financial problems (23\%), cancellations (15\%) or other job-related issues (11\%). Most people who were not going on vacation or who had not decided, planned to stay at home and make same day visits around their neighbourhood.

For those who want $(n=355)$ or don't want to travel $(n=300)$, demographic results show important differences in the intention to go on vacation in terms of marital status, educational background and place of residence, but no significant differences in terms of gender and employment status. There are also significant differences between generations because there is a hierarchy of travel intentions: $66 \%$ amongst Generation X, 55\% amongst Generation Y, 50\% amongst the Baby Boomers and $44 \%$ amongst Generation Z. Finally, these results support RQ2 because there 


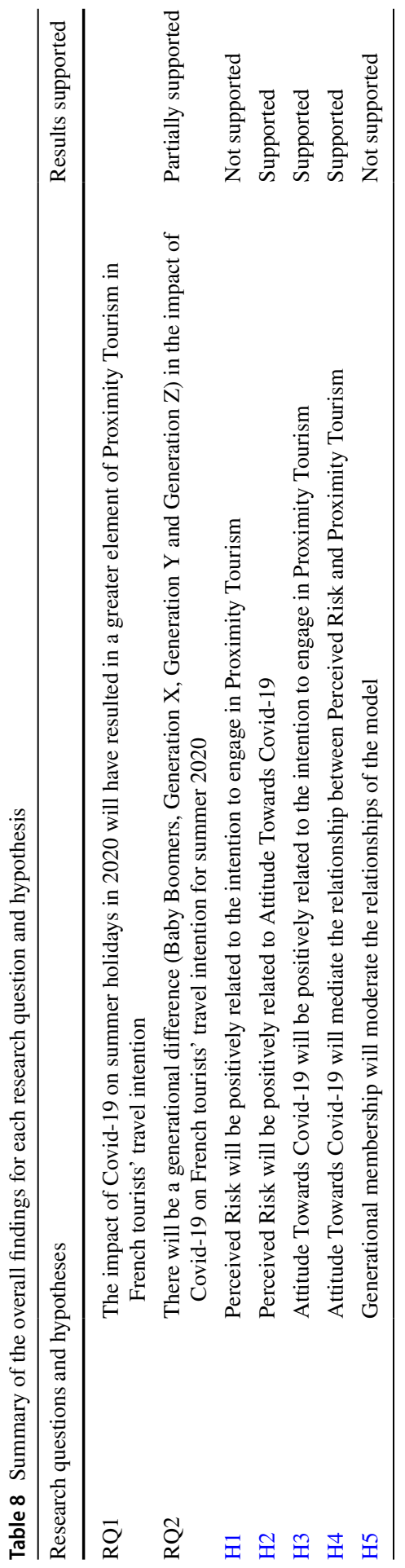


was a generational difference in the impact of Covid-19 on French tourists' travel intention for summer 2020. These findings are consistent with previous research showing that SARS had varying impacts on different types of Chinese people (Wen et al. 2005). These authors indicated that the impact of SARS in China was more serious for older people than it was for younger and middle-aged people, for urban rather than rural tourists and for tourists with high levels of education compared with those with lower levels.

Finally, these comparative results show demographic and generation differences in the intention to go on vacation in summer 2020 caused by a combination of personal uncertainties due to the pandemic (job, financial situation, being afraid to travel...) as well as compulsory state measures (confinement, social distancing, restriction of movement...) and travel bans (cancellations, closed borders, imposed quarantine...) These findings are consistent with Wen et al. (2005) that indicated SARS has greatly affected Chinese people's life, work and travelling in terms of inclination to travel, preference of leisure trips and concern for public hygiene; people tend to be more interested in outdoor activities and ecotourism, and city residents prefer to travel to the suburbs and countryside during the pandemic. Generally speaking, although Covid-19 has aroused panic in a short period of time, leisure or proximity tourism seems to be a highly substitutive activity as people may reduce or postpone travel intention to avoid risk.

In the second part of the analysis, a PLS-SEM model analyses the influence of Perceived Risk and Attitude towards Covid-19 on Proximity Tourism for respondents who planned to travel $(n=355)$. Results show first that there is no influence of Perceived Risk on Proximity Tourism and no moderate effect of Generation on the model. Although only tendentially significant, Perceived Risk is negatively predictive of participants' intention to go in a proximity destination. One can only speculate that perceptions of risk may influence the decision of tourists to go on vacation or not, whether to a proximity or distant destination, due to the uncertainty of the impact of the pandemic in the summer of 2020. This result is consistent with former research on sport mega events such as the Olympic Games (Qi et al. 2009) or the FIFA World Cup (Toohey et al. 2003; Kim and Chalip 2004). In contrast, findings indicate that the different generations do not moderate the relationship between Perceived Risk and Attitude Towards Covid-19 and Proximity Tourism. The lack of moderation of generation could be explained by the weak number of each generation in the sample due certainly to the online process during the outbreak, specifically for the Baby Boomers. Indeed, this result is divergent from the comparative data from the demographic approach that validated RQ2 and is not consistent with research on the impacts of the SARS pandemic in China (Wen et al. 2005).

Thus, PLS-SEM results show (a) positive influence of Perceived Risk on Attitude Towards Covid-19 and of Attitude Towards Covid-19 on Proximity Tourism; (b) that Attitude towards Covid-19 fully mediates the relationship between Perceived Risk and Proximity Tourism ( $C f$. Table 8). These results confirm that Covid19 has encouraged proximity tourism and support the relationship proposed in RQ1. They reinforce the findings of Romagosa (2020) and Nazneen et al. (2020) about the effects of the outbreak on changes in mobility. More specifically, Attitude towards Covid-19 has a double influence. On the one hand, this attitude explains 
the geographical travel intention in favour of Proximity Tourism (or the absence of travel altogether). The Covid-19 pandemic has created anxiety and reduced the distant travel plans of French people for summer 2020. On the other hand, Perceived Risk is experienced as a constraint on travel and therefore may explain the tendency to want to stay somewhere already known, with people who are already familiar, in a region or country without sanitary constraints. This result certainly also explains that Perceived Risk does not positively influence Proximity Tourism because all French people necessarily have to travel in France due to border closures or/and because of the quarantines imposed by other countries, travel bans and cancellations (flights, accommodation, etc.), regardless of their level of perception of the health risk related to the pandemic.

These findings are consistent with a study on tourism in France after the summer vacations (Atout France 2020), which shows that 53\% (71\% in 2019) of French people went travelling in June-August 2020, and further confirms an increased number of visitors from neighbouring territories or regions. Moreover, almost all the respondents in this study who intended to travel were going to do so within France (89\%), which is again consistent with this work (Atout France 2020), showing that $94 \%$ of those who had travelled had stayed in France. More precisely, amongst those who said they intended to travel during their summer 2020 vacation $(n=355)$, their order of preference in terms of destination was firstly within France, followed by within the region and finally outside France. ${ }^{3}$

The PLS-SEM results also show that Attitude Towards Covid-19 fully mediated the relationship between Perceived Risk and Proximity Tourism. This mediation is an original and an important result because the Attitude Towards Covid-19 could be regarded as an important precondition for geographical travel intentions on a proximity destination rather than on a distant destination. Moreover, the mediating role of attitude could be included in future models that are used to study relationships between the perception of sanitary crisis (or health risks) and travel intention (Bae and Chang 2020), behavioural intention (Ajzen 1985; Quintal et al. 2010), destination attractiveness (Reitsamer et al. 2016) or visit intention (Doosti et al. 2016).

\subsection{Managerial implications}

This study could help managers apply proximity marketing strategies for the implementation of tourism services in the context of a global health crisis. In most tourist locations, the development of domestic travel during summer 2020 will probably lead the way to more proximity tourism next year, especially if countries continue to impose strict health measures and limit international travel. Beyond the usual visits to friends or family nearby, it would be interesting for destinations to promote more authentic and/or more specific local holidays with services which develop nature or

\footnotetext{
3 This trend is associated with an increased number of visitors from neighbouring territories or even from the region, ultra-last minute bookings (more than in previous years), shorter trip durations and a difference in the number of French tourists (who have traditionally gone abroad) from previous years (Atout France 2020, p. 5).
} 
outdoor activities and ecotourism (Wen et al. 2005). Such a strategy might include offering more original stays to enable domestic tourists to (re)discover the richness of their local territories (nature, culture, leisure, heritage, gastronomy...) with guides or local greeters capable of providing information and experiences that are more authentic and more adapted to the needs of domestic holidaymakers because they can help them optimize these enjoyable and memorable experiences (Hosany and Witham 2010; Su et al. 2018; Wong and Lee 2012; Wong and Wang 2009; Yim et al. 2012).

For instance, as in the case of rural areas (Campos et al. 2018), managers can promote services with low arousal and more familiar experiences that can provide tourists with creative and repetitive pleasure through the discovery of their own limits, new sensations, new playgrounds... They must also enable more active visitor participation by emphasizing the educational and escapist elements underlying local tourist services. They can create specific activities such as playful visits or areas such as event spaces in which tourists can more easily co-produce and co-create experiences based on their own intellectual and physical resources (Kim and Fesenmaier 2015; Volo 2009). For example, and despite the maintenance of strict sanitary conditions, it would be possible to renew the offer of gastronomy or wine and beer tourism with visits or tastings in vineyards or hop fields. This could take place in small or even intimate groups with knowledge closely linked to local people and culture. A more local and sustainable tourism, in which encounters, culture and leisure activities will have a prominent place, would allow local visitors to travel less far, less often, but better and safer.

In view of the health constraints imposed by the pandemic, the establishment of an effective communication system and digital services will contribute to the recovery of the domestic tourist market. A diversified communication strategy must be deployed by targeting the main social networks (Facebook, Snapchat, YouTube and Instagram) and identifying social media influencers as endorsers to promote local tourism destinations and their services (Belleau et al. 2007; Yussof et al. 2018). Lima et al. (2020) identify social media and destination image as influencing visitors' expectations, and that this image arises out of word-of-mouth communication and tourists' past experiences.

But with the Covid-19 crisis and its more or less long-term consequences, new innovations and digital services should be proposed in tourist destinations (Atout France 2020): health reinsurance of tourist sites (accommodation, equipment, cultural sites, transport infrastructure, etc.) with the implementation of new visitor relationship protocols; new individual or collective protection equipment enabling compliance with health regulations whilst facilitating exchanges, visits and experiences; new management of public traffic flows taking into account the imperatives of social distancing and health constraints both during travel to the destination and on site; creation of innovative solutions for digitizing events, monuments, museums and sites with virtual or augmented reality services; digital, geolocalized, verified promotion of tourists, leisure and cultural services; creation of autonomous augmented reality type services to accompany visits, including on smartphones.

The current Covid-19 pandemic has forced many companies, especially those in the travel and food industries, to quickly develop contactless service solutions using 
robots or digital interfaces (O'Neill 2020). They are used to reduce in-person interaction (employee-customer, employee-employee), serve food and drinks, provide no-touch surface solutions (e.g., using apps instead of printed menus, using contactless payment systems such as Apple Pay instead of credit cards, using smart phones for opening hotel door rooms, controlling room temperature, adjusting lights, operating TV, etc.), provide virtual tours, etc. But for widespread use, consumer inputs and co-creation are necessary to ensure that digital services provide what consumers want with quality and security (Baisch et al. 2017; Čaić et al. 2018; Chiang and Trimi 2020), especially in tourism.

\subsection{Limitations and future research}

This study has some limitations, leading to directions for future research. New studies should be conducted on larger groups of tourists and in other countries to provide external validity of these results. Furthermore, it would be interesting to test the impact of Covid-19 on proximity tourism with other outcomes like transport, accommodation or activities, and to explore other potential moderating variables like gender and place of residence (urban/rural).

Supplementary Information The online version contains supplementary material available at https://doi. org/10.1007/s11628-021-00450-z.

\section{References}

Ajzen I (1985) From intentions to actions: a theory of planned behavior. In: Kuhl J, Beckmann J (eds) Action control. Springer, Berlin, pp 11-39

Ajzen I, Fishbein M (2000) Attitudes and the attitude-behavior relation: reasoned and automatic processes. In: Stroebe W, Hewstone M (eds) European review of social psychology. John Wiley \& Sons, Hoboken, pp 1-33

Ali F, Rasoolimanesh SM, Sarstedt M, Ringle CM, Ryu K (2018) An assessment of the use of partial least squares structural equation modeling (PLS-SEM) in hospitality research. Int J Contemp Hosp Manage 30(1):514-538. https://doi.org/10.1108/IJCHM-10-2016-0568

Atout France (2020) Point de situation - saison touristique estivale en France en 2020, file://C:/Users/ PB1510 1/AppData/Local/Temp/presentation_atf_-_premier_bilan_saison_estivale_4_septembre_2020.pdf

Bae SY, Chang PJ (2020) The effect of coronavirus disease-19 (COVID-19) risk perception on behavioural intention towards 'untact' tourism in South Korea during the first wave of the pandemic. Curr Issues Tourism. https://doi.org/10.1080/13683500.2020.1798895

Baisch S, Kolling T, Schall A, Rühl S, Selic S, Kim Z, Rossberg H, Klein B, Pantel J, Oswald F, Knopf M (2017) Acceptance of social robots by elder people: does psychosocial functioning matter? Int J Soc Robot 9(2):293-307

Bakendorff P, Moscardo G, Pendergast D (2010) Tourism and generation Y. CABI, Oxfordshire

Bauer RA (1960) Consumer behavior as risk taking. In: Hancock RS (ed) Dynamic marketing for a changing world. American Marketing Association, Chicago, pp 389-398

Belleau BD, Summers TA, Xu Y, Pinel R (2007) Theory of reasoned action: purchase intention of young consumers. Cloth Text Res J 25(3):244-257

Bennett J, Pitt M, Price S (2012) Understanding the impact of generational issues in the workplace. Facilities 30(7/8):278-288

Bernstein R (2015) Move over millennials here comes Gen Z. from http://adage.com/article/cmo-strat egy/move-millennials-gen-z/296577/ 
Beutell NJ, Wittig-Berman U (2008) Work-family conflict and work-family synergy for generation X, baby boomers, and matures. J Manag Psychol 23:507-523

Bojanic DC (2011) The impact of age and family life experiences on Mexican visitor shopping expenditures. Tour Manage 32(2):406-414

Breakwell GM (2014) The psychology of risk, 2nd edn. Cambridge University Press, Cambridge

Cabello JM, Navarro-Jurado E, Thiel-Ellul D, Rodríguez-Díaz B, Ruiz F (2020) Assessing environmental sustainability by the double reference point methodology: the case of the provinces of Andalusia (Spain). Int J Sustain Dev World Ecol. https://doi.org/10.1080/13504509.2020.1778582

Cahyanto I, Wiblishauser M, Pennington-Gray L, Schroeder A (2016) The dynamics of travel avoidance: the case of Ebola in the US. Tourism Management Perspectives 20:195-203

Čaić M, Odekerken-Schröder G, Mahr D (2018) Service robots: value co-creation and co-destruction in elderly care networks. J Serv Manage 29(2):178-205

Campos AC, Mendes J, Valle POD, Scott N (2018) Co-creation of tourist experiences: a literature review. Curr Issue Tour 21(4):369-400

Canavan B (2013) The extent and role of domestic tourism in a small island: the case of the Isle of Man. J Travel Res 52(3):340-352

Cennamo L, Gardner D (2008) Generational differences in work values, outcomes and person-organisation values fit. J Manag Psychol 23(8):891-906

Chen CF, Tsai DC (2007) How destination image and evaluative factors affect behavioural intentions? Tour Manage 28(4):1115-1122

Chiang AH, Trimi S (2020) Impacts of service robots on service quality. Serv Bus 14:439-459. https:// doi.org/10.1007/s11628-020-00423-8

Clements JM (2020) Knowledge and behaviors toward Covid-19 amongst us residents during the early days of the pandemic: cross-sectional online Questionnaire. JMIR Public Health Surveill 6(2):19161. https://doi.org/10.2196/19161

Cohen J (1992) Statistical power analysis. Curr Dir Psychol Sci 1(3):98-101

Cortes-Jimenez I (2008) Which type of tourism matters to the regional economic growth? The cases of Spain and Italy. Int J Tour Res 10(2):127-139

DGE (2018) Key facts on tourism in France Edition 2018. https://www.entreprises.gouv.fr/files/files/direc tions_services/etudes-et-statistiques/Chiffres_cles/Tourisme/2019-04-key-facts-on-tourism-2018. pdf (accessed 22 June 2020)

De Vellis RF (2016) Scale development: theory and applications, 4th edn. Sage Publications, Los Angeles

Diaz-Soria I (2017) Being a tourist as a chosen experience in a proximity destination. Tour Geogr 19(1):96-117. https://doi.org/10.1080/14616688.2016.1214976

Dickey J, Sullivan J (2007) Generational Shift in Media Habits. Mediaweek 17(7):10

Dolnicar S (2005) Understanding barriers to leisure travel: tourist fears as a marketing basis. J Vacat Mark 11(3):197-208

Doosti S, Jalilvand MR, Asadi A, Khazaei Pool J, MehraniAdl P (2016) Analyzing the influence of electronic word of mouth on visit intention: the mediating role of tourists' attitude and city image. Int J Tourism Cities 2(2):137-148. https://doi.org/10.1108/IJTC-12-2015-0031

Eugenio-Martin JL, Campos-Soria JA (2014) Economic crisis and tourism expenditure cutback decision. Ann Tour Res 44:53-73

Euromonitor (2018) Generation Z: the next wave of consumers. http://www.portal.euromonitor.com. ezproxy.mdx.ac.uk/portal/analysis/tab/ (accessed 21 June 2018)

Faul F, Erdfelder E, Buchner A, Lang AG (2009) Statistical power analyses using G* Power 3.1: Tests for correlation and regression analyses. Behav Res Methods 41(4):1149-1160

Fennell DA (2008) Responsible tourism: a Kierkegaardian interpretation. Tour Recreat Res 33(1):3-12

Floyd MF, Gibson H, Pennington-Gray L (2001) Thapa B (2003) The effect of risk perceptions on intentions to travel in the aftermath of September 11. J Travel Tour Mark 15(2/3):19-38

Fornell C, Larcker DF (1981) Structural equation models with unobservable variables and measurement error: algebra and statistics. J Market Res 18(3):382-388

Franke G, Sarstedt M (2019) Heuristics versus statistics in discriminant validity testing: a comparison of four procedures. Internet Res 29(3):430-447

Fuchs G, Reichel A (2006) Tourist destination risk perception: The case of Israel. J Hosp Leisure Market 14(2):83-108. https://doi.org/10.1300/J150v14n02_06

Gardiner S, King C, Grace D (2013) Travel decision-making: an empirical examination of generational values, attitudes, and intentions. J Travel Res 52(3):310-324 
Gardiner S, Grace D, King C (2014) The generation effect: The future of domestic tourism in Australia. J Travel Res 53(6):705-720

Garson GD (2016) Partial least squares: Regression and structural equation models. Statistical Associates Publishing, Asheboro

Gaskin CJ, Happell B (2014) On exploratory factor analysis: a review of recent evidence, an assessment of current practice, and recommendations for future use. Int J Nurs Stud 51(3):511-521

Gentina E (2019) Generation Z in France: reverse socialisation and social engagement. In: Scholz C, Rennig A (eds) Generations $\mathrm{Z}$ in Europe (the changing context of managing people). Emerald Publishing Limited, New York, pp 109-126

George R (2010) Visitor perceptions of crime-safety and attitudes towards risk: the case of Table Mountain National Park. Cape Town Tourism Manage 31(6):806-815

Glover P (2010) Generation Y's future tourism demand: some opportunities and challenges. In: Bakendorff P, Moscardo G, Pendergast D (eds) Tourism and generation Y. CABI, Oxfordshire, pp 155-164

Glover P, Prideaux B (2008) Using population projections to identify aspects of future tourism demand. Adv Hosp Leisure 4(4):185-209

Hair JF, Hult GTM, Ringle CM, Sarstedt M (2014) Partial least squares structural equation modeling (PLS-SEM). Sage, Thousand Oaks

Hair JF, Gabriel MLDS, Da Silva D, Junior SB (2019a) Development and validation of attitudes measurement scales: fundamental and practical aspects. RAUSP Manage J 54(4):490-507

Hair JF, Risher JJ, Sarstedt M, Ringle CM (2019b) When to use how to report the results of PLS-SEM. Eur Bus Rev 31(1):2-24

Henseler J, Ringle CM, Sarstedt M (2015) A new criterion for assessing discriminant validity in variance-based structural equation modeling. J Acad Mark Sci 43(1):115-135

Henseler J, Ringle CM, Sarstedt M (2016) Testing measurement invariance of composites using partial least squares. Int Mark Rev 33(3):405-431

Himmel B (2008) Different strokes for different generations. Rental Product News 30(7):42-46

Hosany S, Witham M (2010) Dimensions of cruisers' experiences, satisfaction, and intention to recommend. J Travel Res 49(3):351-364

Hu LT, Bentler PM (1998) Fit indices in covariance structure modeling: sensitivity to underparameterized model misspecification. Psychol Methods 3(4):424

Hu LT, Bentler PM (1999) Cutoff criteria for fit indexes in covariance structure analysis: conventional criteria versus new alternatives. Struct Equ Model 6(1):1-55

Huang Y, Petrick JF (2009) Generation Y's travel behaviours: a comparison with baby boomers and generation X. In: Bakendorff P, Moscardo G, Pendergast D (eds) Tourism and generation Y. CABI, Oxfordshire, pp 27-37

Hudson RB (2010) Contemporary challenges to aging policy. New Polit Old Age Policy 4:87

Hudson S, Ritchie JBR (2002) Understanding the domestic market using cluster analysis: a case study of the marketing efforts of travel Alberta. J Vacat Mark 8(3):263-276

Jeuring JHG (2017) Weather perceptions, holiday satisfaction and perceived attractiveness of domestic vacationing in The Netherlands. Tour Manage 61:70-81

Jeuring JHG, Haartsen T (2016) Destination branding by residents: the role of perceived responsibility in positive and negative word-of-mouth. Tourism Plann Dev. https://doi.org/10.1080/21568316.2016. 1214171

Jeuring JHG, Haartsen T (2017) The challenge of proximity: the (un) attractiveness of near-home tourism destinations. Tour Geogr 19(1):118-141. https://doi.org/10.1080/14616688.2016.1175024

Jittrapirom P, Tanaksaranond G (2020) An exploratory survey on the perceived risk of COVID-19 and travelling. https://doi.org/10.31235/osf.io/v3g5d

Kastenholz E (2010) 'Cultural proximity' as a determinant of destination image. J Vacat Mark 16(4):313-322

Khan MJ, Chelliah S, Khan F, Amin S (2019) Perceived risks, travel constraints and visit intention of young women travelers: the moderating role of travel motivation. Tourism Review 74(3):721-738

Kim N, Chalip L (2004) Why travel to the FIFA World Cup? Effects of motives, background, interest, and constraints. Tour Manage 25:695-707

Kim JH, Fesenmaier DR (2015) Measuring emotions in real time: Implications for tourism experience design. J Travel Res 54(4):419-429

Kozak M, Crotts JC, Law R (2007) The impact of the perception of risk on international travellers. Int J Tour Res 9(4):233-242 
Laliberté M (2005) La génération X pousse les «boomers» vers la sortie!, Le Globveilleur, Le bulletin électronique du Réseau de veille en tourisme, Réseau de veille en tourisme, Chaire de Tourisme, École des sciences de la gestion UQAM, Edition du 1er juin, 1-3

Larsen GR, Guiver JW (2013) Understanding tourists' perceptions of distance: a key to reducing the environmental impacts of tourism mobility. J Sustain Tour 21(7):968-981

Lebrun AM, Corbel R (2019) L'efficacité de la communication pour la marque de destination urbaine: représentations de touristes et de résidents. Téoros: Revue de Recherche en Tourisme. https://doi. org/10.7202/1065647ar

Lee TH (2009) A structural model to examine how destination image, attitude, and motivation affect the future behavior of tourists. Leis Sci 31:215-236

Lee C, Hallak R (2018) Investigating the moderating role of education on a structural model of restaurant performance using multi-group PLS-SEM analysis. J Bus Res 88:298-305

Lew A (2020) How to create a better post-COVID-19 World. Medium 16 March 2020. https://medium. com/@alanalew/creating-a-better-post-covid-19-world-36b2b3e8a7ae

Lima MM, Mainardes EW, Rodrigues RG (2020) Tourist expectations and perception of service providers: a Brazilian perspective. Serv Bus 14:131-166. https://doi.org/10.1007/s11628-019-00406-4

Lyons S, Duxbury L, Higgins C (2005) Are gender differences in basic human values a generational phenomenon? Sex Roles 53:763-778

Mannheim K (1952) The problem of generations. In: Kecskemeti P (ed) Essays on the sociology of knowledge. Collected works of Karl Mannheim. Routledge and Kegan Paul, London, pp 276-322

Mansfeld Y (2006) The role of security information in tourism crisis management: the missing link. In: Mansfeld Y, Pizam A (eds) Tourism, security and safety: from theory to practice. Elsevier, Oxford, pp 271-290

Marjanen H, Kohijoki AM, Saastamoinen K, Engblom J (2019) Old dogs learning new tricks? The effect of age and generation on shopping behaviour. Int Rev Retail Distrib Consumer Res 29(5):549-567

Matsunaga M (2010) How to factor-analyze your data right: do's, don'ts, and how-to's. Int J Psychol Res 3(1):97-110

Matthews L (2017) Applying multigroup analysis in PLS-SEM: A step-by-step process. In: Latan H, Noonan R (eds) Partial least squares path modeling. Springer, Cham, pp 219-243

McKercher B, Chon K (2004) The over-reaction to SARS and the collapse of Asian tourism. Ann Tour Res 31(3):7-16

Melián-González S, Gutiérrez-Taño D, Bulchand-Gidumal J (2021) Predicting the intentions to use chatbots for travel and tourism. Curr Issue Tour 24(2):192-210

Meredith GE, Schewe CD (1994) Cohort effects and life insurance. Market Manage 3(3):21-35

Merriman M (2015) What if the next big disruptor isn'ta what but a who. Ernst and Young. https://www. ey.com/Publication/vwLUAssets/EY-rise-of-gen-znew-challenge-for-retailers/\%24FILE/EY-riseof-gen-znew-challenge-for-retailers.pdf (accessed 21 June 2018)

Mohsin A (2005) Tourist attitudes and destination marketing-the case of Australia's northern territory and Malaysia. Tour Manage 26:723-732

Moreira P (2007) Aftermath of crises and disasters: notes for an impact assessment approach. In: Laws E, Prideaux B, Chon KS (eds) Crisis management in tourism. CABI, Oxfordshire, pp 51-65

Nazneen, Xu UD, Nizam, Covid-19 crises and tourist travel risk perceptions (May 4, 2020). https://doi. org/10.2139/ssrn.3592321

Noble SM, Schewe CD (2003) Cohort segmentation: an exploration of its validity. J Bus Res 56(12):979-987

Noble SM, Schewe CD, Kuhr M (2004) Preferences in health care service and treatment: a generational perspective. J Bus Res 57:1033-1041

Noble SM, Haytko DL, Phillips J (2009) What drives college-age generation Y consumers? J Bus Res 62:617-628

Noh J, Vogt C (2013) Modelling information use, image, and perceived risk with intentions to travel to East Asia. Curr Issue Tour 16(5):455-476

Ollivier D, Tanguy C (2017) Générations Y and Z: le grand défi intergénérationnel. De Boeck Supérieur, Paris

Opperman M (1995) Family life cycle and cohort effects: A study of travel patterns of German residents. J Travel Tour Mark 4(1):23-45

O'Neill, S (2020) Contactless tech promises to be travel's next big thing: what is real and what is hype? Skift. https://skift.com/2020/06/04/contactless-tech-promises-to-be-travels-next-big-thing-whatsreal-and-whats-hype/ (accessed May 23, 2020) 
Park J, Gursoy D (2012) Generation effects on work engagement amongst US hotel employees. Int J Hosp Manag 31(4):1195-1202

Patterson I, Sie L, Balderas-Cejudo A, Rivera-Hernaez O (2017) Changing trends in the baby boomer travel market: importance of memorable experiences. J Hosp Market Manag 26(4):347-360

Pearce PL (1990) Farm tourism in New Zealand: a social situation analysis. Ann Tour Res 17(3):337-352

Pennington-Gray L, Spreng RA (2001) Analyzing changing preferences for pleasure travel with cohort analysis. Tour Anal 6(2):109-121

Pennington-Gray L, Kerstetter DL, Warnick R (2002) Forecasting travel patterns using Palmore's cohort analysis. J Travel Tour Mark 13:125-143

Pennington-Gray L, Fridgen JD, Stynes D (2003) Cohort segmentation: an application to tourism. Leis Sci 25:341-361

Prideaux B (2004) A time of generational change: will Norfolk Island's tourism industry be ready? Proc New Zealand Tourism Hosp Res Conf 2004(2):286-294

Qi CX, Gibson HJ, Zhang JJ (2009) Perceptions of risk and travel intentions: the case of China and the Beijing Olympic Games. J Sport Tourism 14(1):43-67. https://doi.org/10.1080/147750809028474 39

Qu H, Kim LH, Im HH (2011) A model of destination branding: integrating the concepts of the branding and destination image. Tour Manage 32(3):465-476

Quintal VA, Lee JA, Soutar GN (2010) Risk, uncertainty and the theory of planned behavior: a tourism example. Tour Manage 31(6):797-805. https://doi.org/10.1016/j.tourman.2009.08.006

Ragheb MG, Tate RL (1993) A behavior model of leisure participation, based on leisure attitude, motivation and satisfaction. Leis Stud 12:61-67

Rantala O, Salmela T, Valtonen A, Höckert E (2020) Envisioning tourism and proximity after the anthropocene. Sustainability 12(10):39-48

Rasoolimanesh SM, Khoo-Lattimore C, Md Noor S, Jaafar M, Konar R (2021) Tourist engagement and loyalty: gender matters? Curr Issue Tour 24(6):871-885

Reichel A, Fuchs G, Uriely N (2007) Perceived risk and the non-institutionalized tourist role: the case of Israeli student ex-backpackers. J Travel Res 46(2):217-226. https://doi.org/10.1177/0047287507 299580

Reitsamer BF, Brunner-Sperdin A, Stokburger-Sauer NE (2016) Destination attractiveness and destination attachment: the mediating role of tourists' attitude. Tourism Manage Perspect 19:93-101. https://doi.org/10.1016/J.TMP.2016.05.003

Remuzzi A, Remuzzi G (2020) Covid-19 and Italy: what next? The Lancet. https://doi.org/10.1016/ S0140-6736(20)30627-9

Ringle C, Da Silva D, Bido D (2015) Structural equation modeling with the SmartPLS. REMark: Revista Brasileira de Marketing 13(2):56-73

Ritchie B (2004) Chaos, crises and disasters: a strategic approach to crisis management in the tourism industry. Tour Manage 25(6):669-683

Ritchie BW, Campiranon K (eds) (2014) Tourism crisis and disaster management in the Asia-Pacific (Vol 1). CABI, Oxfordshire

Rittichainuwat BN (2006) Tsunami recovery: a case study of Thailand's tourism. Cornell Hotel Act Admin Q 47(4):390-404

Rittichainuwat BN, Chakraborty G (2009) Perceived travel risks regarding terrorism and disease: the case of Thailand. Tour Manage 30(3):410-418

Roberts JA, Manolis C (2000) Baby boomers and busters: an exploratory investigation of attitudes toward marketing, advertising and consumerism. J Consum Mark 17:481-499

Rochford L (2016) Contrepoint 'Les générations futures, c’est nous!' Informations Sociales 4:126-126. https://doi.org/10.3917/inso.195.0126

Roehl W, Fesenmaier D (1992) Risk perceptions and pleasure travel: an exploratory analysis. J Travel Res 30(4):17-26. https://doi.org/10.1177/004728759203000403

Romagosa F (2020) The COVID-19 crisis: opportunities for sustainable and proximity tourism. Tourism Geogr. https://doi.org/10.1080/14616688.2020.1763447

Ruangkanjanases A, Wongprasopchai S (2017) Factors influencing customer adoption of mobile banking services: empirical examination between generation $\mathrm{Y}$ and generation $\mathrm{Z}$ in Thailand. Adv Sci Lett 23(1):628-633

Sadique MZ, Edmunds WJ, Smith RD, Meerding WJ, De Zwart O, Brug J, Beutels P (2007) Precautionary behavior in response to perceived threat of pandemic influenza. Emerg Infect Dis 13(9):1307-1313 
Salazar NB (2012) Tourism imaginaries: a conceptual approach. Ann Tour Res 39(2):863-882

Schewe CD, Noble SM (2000) Market segmentation by cohorts: the value and validity of cohorts in America and abroad. J Mark Manag 16:123-142

Schewe CD, Meredith GE, Noble SM (2000) Defining moments: segmenting by cohorts. Market Manage 9:48-53

Schroeder A, Pennington-Gray L, Kaplanidou K, Zhan F (2013) Destination risk perceptions amongst US residents for London as the host city of the 2012 Summer Olympic Games. Tour Manage 38:107-119

Schuman H, Scott J (1989) Generations and Collective Memories. Am Sociol Rev 54:359-381

Seabra C, Dolnicar S, Abrantes JL, Kastenholz E (2013) Heterogeneity in risk and safety perceptions of international tourists. Tour Manage 36:502-510

Seemiller C, Grace M, Dal Bo CP, Da Rosa M, Alves I, Severo De Borba G (2019) How generation Z college students prefer to learn: a comparison of us and brazil students. J Educ Res Pract 9(1):349368. https://doi.org/10.5590/JERAP.2019.09.1.25

Skinner H, Sarpong D, White GR (2018) Meeting the needs of the Millennials and Generation Z: gamification in tourism through geocaching. J Tourism Futures 4(1):93-104. https://doi.org/10.1108/ JTF-12-2017-0060

Strauss W, Howe N (1991) Generations: the history of America's future. Quill, New York

Stylidis D, Belhassen Y, Shani A (2017) Destination image, on-site experience and behavioural intentions: path analytic validation of a marketing model on domestic tourists. Curr Issue Tour 20(15):1653-1670. https://doi.org/10.1080/13683500.2015.1051011

Su CJ, Lebrun AM, Bouchet P, Wang JR, Lorgnier N, Yang JH (2018) Tourists' participation and preference-related belief in co-creating value of experience: a nature-based perspective. Serv Bus 10(4):823-846

Szytniewski BB, Spierings B, Van der Velde M (2017) Sociocultural proximity, daily life and shopping tourism in the Dutch-German border region. Tour Geogr 19(1):63-77. https://doi.org/10.1080/ 14616688.2016.1233289

Sönmez S (1998) Tourism, terrorism and political instability. Ann Tour Res 25(2):416-456

Sönmez SF, Graefe AR (1998a) Influence of terrorism risk on foreign tourism decisions. Ann Tour Res 25(1):112-144

Sönmez SF, Graefe AR (1998b) Determining future travel behavior from past travel experience and perceptions of risk and safety. J Travel Res 37(2):171-177

TSA (2019) Tourism Satellite Accounts in Europe Edition 2019, Accessed date: September 23, 2020. https://ec.europa.eu/eurostat/documents/7870049/10293066/KS-FT-19-007-EN-N.pdf/f9cdc4cc882b-5e29-03b1-f2cee82ec59d

Tabachnick BG, Fidell LS (2007) Using multivariate statistics, 5th edn. Pearson Allyn and Bacon, Upper Saddle River

Toohey K, Taylor T, Lee C (2003) The FIFA World Cup 2002: the effects of terrorism on sport tourists. J Sport Tourism 8:167-185

Um S, Crompton JL (1990) Attitude determinants in tourism destination choice. Ann Tour Res 17(3):432-448

Volo S (2009) Conceptualizing Experience: a tourist based approach. J Hosp Market Manag $18(2-3): 111-126$

Wang CY, Hsu MK (2010) The relationships of destination image, satisfaction, and behavioural intentions: an integrated model. J Travel Tour Mark 27(8):829-843

Wen Z, Huimin G, Kavanaugh RR (2005) The impacts of SARS on the consumer behaviour of Chinese domestic tourists. Curr Issue Tour 8(1):22-38

Wilks J, Pendergast D, Leggat P (2006) Tourism in turbulent times. Routledge, New York

Wise T, Zbozinek TD, Michelini G, Hagan CC (2020) Changes in risk perception and protective behavior during the first week of the COVID-19 pandemic in the United States https://doi.org/10.31234/osf. io/dz428

Wong JY, Wang CH (2009) Emotional labor of the tour leaders: an exploratory study. Tour Manage 30(2):249-259

Wong JY, Lee WH (2012) Leadership through service: an exploratory study of the leadership styles of tour leaders. Tour Manage 33(5):1112-1121

Wynen J (2013) Explaining travel distance during same-day visits. Tour Manage 36:133-140

Yang Y, Liu ZH, Qi Q (2014) Domestic tourism demand of urban and rural residents in China: does relative income matter? Tour Manage 40:193-202 
Yim CK, Chan KW, Lam S (2012) Do customers and employees enjoy service participation? Synergistic effects of self- and other-efficacy. J Mark 76(6):121-140

You X, O'Leary J (2000) Age and cohort effects: an examination of Older Japanese Travelers. J Travel Tour Mark 9(1/2):21-42

Yussof FM, Harun A, Norizan NS, Durani N, Jamil I, Salleh SM (2018) The influence of social media consumption on gen Z consumers' attitude. J Fundam Appl Sci 10(6S):1288-1299

Publisher's Note Springer Nature remains neutral with regard to jurisdictional claims in published maps and institutional affiliations. 